\title{
Soil physical properties and soil organic carbon content in northeast Brazil: long-term
}

\section{tillage systems effects}

\author{
Fernanda Cristina Caparelli Oliveira ${ }^{1 *} \oplus^{\oplus}$, Gabriel William Dias Ferreira ${ }^{2 \oplus}$, João Lucas Santos Souza ${ }^{3 \oplus}$, Matheus Emannuel Oliveira \\ Vieira ${ }^{3 \oplus}$, Alceu Pedrotti ${ }^{\circledR}$
}

\author{
'Universidade Federal de Sergipe, Av. Marechal Rondon, $s / n$ \\ - 49100-000 - São Cristovão, SE - Brasil. \\ 2Universidade Federal de Lavras - Depto. Ciências \\ Florestais, C.P. 3037 - 37200-000 - Lavras, MG - Brasil. \\ 3Universidade Federal de Sergipe - Depto. de Engenharia \\ Agronômica. \\ *Corresponding author <nandacaparelli@gmail.com>
}

Edited by: Silvia del Carmen Imhoff

Received May 17, 2018

Accepted December 09, 2018
ABSTRACT: Concerns about the negative effects of agriculture on soil physical quality and soil organic carbon ( $\mathrm{SOC}$ ) pools have spurred on the adoption of conservation tillage systems in tropical regions. This study aimed to evaluate the long-term impacts ( $16^{\text {th }}$ year) of conventional (CT), minimum (MT) and no-tillage (NT) practices and different cover crops (sunn hemp and a bean/ millet sequence) on soil physical properties and SOC content of a corn cultivated Ultisol in the northeast of Brazil. Soil bulk density (Bd), soil penetration resistance (SPR), soil aggregation, and total aggregate-associated carbon (C) $(4-2 \mathrm{~mm})$ were evaluated. Tillage practices exerted strong control on soil physical properties and total aggregate- $C$ content but were influenced by cover crop species. Minimum tillage presented the lowest Bd, irrespective of cover crop, while NT with bean/millet sequence resulted in the lowest SPR. However, as regards soil aggregation and total aggregate- $C$, the results indicated that there were no differences between MT and NT, with both systems presenting greater mean weight diameter (MWD) and total aggregate- $\mathrm{C}$ content than CT. Total aggregate- $C$ content in the 0.00-0.05 m soil layer in conservation tillage was increased by the adoption of a bean/millet sequence. Increased mechanical disturbance through CT practices was harmful to Bd, soil aggregation and SOC accrual. Overall, more conservative tillage practices and the proper choice of cover crops might yield greater soil quality. Low intensity of soil disturbances due to the adoption of MT favors soil aggregation and the accrual of SOC in weakly structured soils through increases in contact between organic and mineral particles while not causing significant destruction of soil aggregates.

Keywords: no-till cropping systems, minimum-tillage, soil bulk density, mean weight diameter, total aggregate-associated carbon

\section{Introduction}

Soil degradation is a recurrent problem in tropical countries that implies declining ecosystem services and soil quality. Soil physical degradation involves reduction of soil structure, leading to soil compaction, wind and water erosion and soil organic carbon (SOC) mineralization. Although certain classes of soil are more prone to degradation, for instance, Inceptisols and Ultisols (Carvalho et al., 2014), soil mismanagement and land misuse, i.e. indiscriminate plowing and negative SOC budgets may exacerbate soil quality decline (Lal, 2015). Ultisols cover c.a. $20 \%$ of the land area of northeastern Brazil and, specifically in the region of the coastal tableland, are characterized by low natural fertility and cation exchange capacity in the upper horizons, along with hard setting behavior in subsurface soil horizons (cohesive horizons).

Positive effects on soil porosity (Gao et al., 2017), aggregate stability (Moraes et al., 2016) and soil organic matter (SOM) stocks (Sá et al., 2009) across a wide range of soil types and climates are attributable to conservation tillage systems. However, the beneficial influence of conservation tillage practices, such as no or reduced soil disturbance, cover cropping and residue retention on soil physical properties and SOM apparently rely on site-specific interactions, post-adoption period, climate conditions, the properties of the former management system, and the choice of cover crop species (Derpsch et al., 2014; Hubbard et al., 2013). Nonetheless, most conservation tillage studies in Brazil have concentrated on Oxisols in the southern region (Moraes et al., 2016; Sá et al., 2009; Suzuki et al., 2013), while data to support the decision regarding the adoption of conservation tillage in northeastern Brazil are scarce.

The overarching goal of this work was to expand our knowledge of the impact of conservation agriculture on soil physical quality and SOC content in a particular data-scanty region in Brazil. To that end, we took advantage of a long-term experiment of sweet corn production in an Ultisol in the region of the coastal tableland in northeastern Brazil and analyzed soil bulk density $(\mathrm{Bd})$, soil penetration resistance (SPR), soil aggregation and total aggregate-associated carbon (C) content in the $16^{\text {th }}$ year of conventional $(\mathrm{CT})$, minimum (MT) and no-tillage (NT) adoption combined with different cover crops.

\section{Materials and Methods}

\section{Site description and experimental design}

The study was carried out at an experimental site located in São Cristovão, SE, Brazil $\left(10^{\circ} 55^{\prime} 24^{\prime \prime} S_{\text {; }}\right.$ $37^{\circ} 11^{\prime} 57^{\prime \prime} \mathrm{W}$ ) at an altitude of approximately $25 \mathrm{~m}$ above sea level. The local climate is tropical (As), according to 
Köppen's classification with wet winters and dry summers (Alvares et al., 2013). Mean annual temperature and precipitation have been, on average, $26.7^{\circ} \mathrm{C}$ and $1,084 \mathrm{~mm}$, respectively, over the last two decades. The soil was classified as a Typic Hapludult (Soil Survey Staff, 2014), weakly structured, with $790 \mathrm{~g} \mathrm{~kg}^{-1}$ sand, $70 \mathrm{~g} \mathrm{~kg}^{-1}$ clay and $140 \mathrm{~g} \mathrm{~kg}^{-1}$ silt, and mineralogy dominated by quartz and kaolinite to a depth of $0.20 \mathrm{~m}$. Ultisols from this region have for decades been exploited for sweet corn production by smallholder farmers. Corn is cultivated between one and three times a year at sites with or without irrigation, respectively, and tillage practices such as plowing and harrowing are commonly employed in this region.

The experiment had been annually repeated through 15 years. First, the experimental area was equally split into three plots. Next, each plot was divided into six experimental units $(\mathrm{EU})(6 \times 10 \mathrm{~m}), 1 \times 10 \mathrm{~m}$ distant from each other.

Three tillage practices (CT, MT and NT) were laid out as whole plots. In each plot, the cover crops, sunn hemp (Crotalaria juncea L.) and a bean/millet (Phaseolus vulgaris L. / Pennisetum glaucum L.) sequence, were randomly distributed across the EU, with three replicates each. Conventional tillage consisted of moldboard plowed to a depth of $0.20 \mathrm{~m}$ followed by two harrowings down to the same depth to break the clods. Minimum tillage consisted of only two $0.20 \mathrm{~m}$ harrowing. Soil tillage practices were implemented twice a year, preceding cover crop and corn seeding. In NT treatments, seeds were sown directly without plowing or harrowing, and weeds chemically controlled with glyphosate [isopropylamine salt of $N$-(phosphonomethyl) glycine] and $2.4 \mathrm{D}$ (2.4-dichlorophenoxyacetic acid).

Over the course of this experiment, cover crops were sown manually $(0.50 \times 0.20 \mathrm{~m})$ each year between Jan and Mar and were cut $~ 75$ days after seeding. Sunn hemp was cropped from the beginning of the experiment, while bean was cultivated for 12 years and then replaced by millet. Both cover crops received $27 \mathrm{~kg} \mathrm{ha}^{-1} \mathrm{~N}, 15 \mathrm{~kg}$ $\mathrm{ha}^{-1} \mathrm{P}_{2} \mathrm{O}_{5}$ and $40 \mathrm{~kg} \mathrm{ha}^{-1} \mathrm{~K}_{2} \mathrm{O}$ at sowing.

Mechanical corn (Zea mays L.) sowing at 62,500 seeds ha-1 $(0.80 \times 0.20 \mathrm{~m})$ was carried out annually between Apr and June. Liming and mineral fertilization were applied according to recommendations by Sobral et al. (2007). Irrigation was applied through an overhead sprinkler system during cover crop and corn growth as needed based on rainfall events. After the sweet corn harvesting, the aboveground biomass was cut and disposed of on the soil surface.

\section{Soil sampling and laboratory measurements}

Soil sampling was carried out in the $16^{\text {th }}$ year of experiment cultivation, soon after sweet corn harvesting. Undisturbed soil samples were obtained from the center of the 0.00-0.10 and 0.10-0.20 m layers, using cores with a $0.04 \mathrm{~m}$ diameter and $0.05 \mathrm{~m}$ in height, to determine $\mathrm{Bd}$ and soil moisture content. Three cores were obtained for each depth and replicate. Soil penetration resistance was measured using a digital penetrometer model and recorded at each $0.01 \mathrm{~m}$ increment down to a depth of $0.20 \mathrm{~m}$. Soil penetration resistance at 0.00-0.10 and 0.10$0.20 \mathrm{~m}$ was calculated as the mean SPR measured at each soil depth. Ten SPR measurements were made per EU without manipulating the soil moisture content, i.e. under field conditions.

Subsequently, an additional undisturbed soil sample was randomly collected at each EU from a center point in the $0.00-0.05,0.05-0.10$ and $0.10-0.20 \mathrm{~m}$ soil layers, air-dried, and gently crushed to obtain 4 to $2 \mathrm{~mm}$ sized aggregates. For aggregate stability, a subsample of the air-dried aggregates $(4-2 \mathrm{~mm})$ was slowly rewetted by capillarity and then separated by wet-sieving as adapted from the Yoder method: $25 \mathrm{~g}$ were transferred to a set of sieves with 2, 1, 0.5, 0.205 and $0.106 \mathrm{~mm}$ apertures, and submerged in distilled water at room temperature for eight minutes at roughly $30 \mathrm{rpm}$. Each sample was analyzed in duplicate. Aggregate stability was measured by mean weight diameter (MWD), based on the proportion of total dry weight retained in each sieve and the mean diameter of each fraction size. To determine total aggregate-associated $\mathrm{C}$ content, a subsample of the same airdried initial class $4-2 \mathrm{~mm}$ aggregate was sieved $(<2 \mathrm{~mm})$ to determine SOC (Yeomans and Bremner, 1988). Thus, rather than SOC content from $<2 \mathrm{~mm}$ soil samples, we determined the total aggregate-associated $\mathrm{C}$, i.e., the total $\mathrm{C}$ content associated with the initial 4-2 mm aggregate-size class. This SOC fraction was used because it represents a fraction which is sensitive to organic fresh inputs and soil disturbances, and plays a critical role in the aggregation of sandy soils (Elliott, 1986; Six et al., 2004; Six and Paustian, 2014).

\section{Data analysis}

Data normality was assessed by the Shapiro-Wilk test, and Box-Cox data transformation was carried out when the normality assumption was not met. Statistical analysis of the data $(\mathrm{Bd}, \mathrm{SPR}, \mathrm{MWD}$ and total aggregate$\mathrm{C}$ content) was performed using a three-way repeated measure ANOVA procedure with tillage practices, cover crops and soil layer as independent factors. The independent factor interactions inside ANOVA were decomposed and means were compared by post-hoc Tukey's test $(p<0.05)$. All statistical analyses were carried out using the Sisvar ${ }^{\circledR}$ program (version 5.6).

\section{Results}

\section{Bulk density and soil penetration resistance}

Cover crops had little or no effect on Bd and SPR (Table 1). Conversely, Bd was affected by tillage practices: Bd in both soil layers was lower in MT than in CT and NT, but there was no difference between CT and NT.

Soil penetration resistance in the $0.00-0.10 \mathrm{~m}$ soil layer did not differ between tillage practices in sunn 
hemp plots; however, it should be considered that MT and NT had lower soil moisture content than CT (Table 1). In bean/millet plots, NT resulted in the lowest SPR in both soil layers. Cover crops influenced SPR in the 0.10-0.20 m soil layer, i.e. a lower SPR was observed on bean/millet than on sunn hemp plots under NT practices (Table 1). Conversely, cover crop species did not alter SPR in MT treatment; although, sunn hemp had a higher soil moisture content than bean/millet plots.

\section{Soil aggregation and total aggregate-associated carbon content}

The tendency was for the tillage effects on MWD and total aggregate-C content to be limited to the uppermost soil layer $(0.00-0.10 \mathrm{~m})$ and to be dependent upon the cover crop species (Figure 1A, B, D and E). Notillage resulted in higher MWD in the $0.00-0.10 \mathrm{~m}$ soil layer than CT in plots with sunn hemp but did not differ from MWD under MT (Figure 1A and B). There was no difference in MWD in the bean/millet plots caused by tillage practices (Figure 1A, B and C). Mean weight diameter decreased with depth in $\mathrm{MT}$ and $\mathrm{NT}$, while no change was observed in CT (Figure $1 \mathrm{~A}, \mathrm{~B}$ and $\mathrm{C}$ ). In the 0.10-0.20 $\mathrm{m}$ soil layer of $\mathrm{CT}$, bean/millet plot resulted in greater aggregate stability than sunn hemp (Figure 1C).

Adopting NT and MT resulted in total aggregate$C$ increase $(\sim 80 \%)$ in the $0.00-0.05 \mathrm{~m}$ soil layer compared with CT (Figure 1D). Conversely, there was no difference in total aggregate-C content in the 0.05-0.10 $\mathrm{m}$ soil layer caused by tillage practices under sunn hemp

Table 1 - Effects of tillage practices [conventional (CT), minimum (MT) and no-tillage (NT)] and cover crops on soil bulk density, soil penetration resistance and soil moisture.

\begin{tabular}{|c|c|c|c|c|c|c|c|}
\hline \multirow{2}{*}{ Tillage } & \multirow{2}{*}{ Cover crops } & \multicolumn{2}{|c|}{ Bulk density $\left(\mathrm{g} \mathrm{cm}^{-3}\right)$} & \multicolumn{2}{|c|}{ Soil penetration resistance (MPa) } & \multicolumn{2}{|c|}{ Soil moisture $\left(\mathrm{g} \mathrm{g}^{-1}\right.$ ) } \\
\hline & & $0.00-0.10 \mathrm{~m}$ & $0.10-0.20 \mathrm{~m}$ & $0.00-0.10 \mathrm{~m}$ & $0.10-0.20 \mathrm{~m}$ & $0.00-0.10 \mathrm{~m}$ & $0.10-0.20 \mathrm{~m}$ \\
\hline \multirow[b]{2}{*}{ CT } & sunn hemp & $1.63( \pm 0.04) \mathrm{Aa}$ & $1.70( \pm 0.05) \mathrm{Aa}$ & $1.88( \pm 0.08) \mathrm{Ab}$ & $5.05( \pm 0.24) \mathrm{Ba}$ & $0.09( \pm 0.02) \mathrm{Aa}$ & $0.05( \pm 0.01) \mathrm{Ab}$ \\
\hline & bean/millet & $1.64( \pm 0.05) \mathrm{Ab}$ & $1.77( \pm 0.04) \mathrm{Aa}$ & $2.06( \pm 0.09) \mathrm{ABb}$ & $5.13( \pm 0.24) \mathrm{Ba}$ & $0.10( \pm 0.02) \mathrm{Aa}$ & $0.06( \pm 0.02) \mathrm{Ab}$ \\
\hline \multirow{2}{*}{ MT } & sunn hemp & $1.42( \pm 0.02) \mathrm{Ba}$ & $1.47( \pm 0.04) \mathrm{Ba}$ & $2.36( \pm 0.11) \mathrm{Ab}$ & $6.27( \pm 0.30) \mathrm{Aa}$ & $0.05( \pm 0.00) \mathrm{Ba}$ & $\mathbf{0 . 0 6}( \pm 0.02) \mathrm{Aa}$ \\
\hline & bean/millet & $1.47( \pm 0.02) \mathrm{Ba}$ & $1.48( \pm 0.04) \mathrm{Ba}$ & $2.52( \pm 0.07) \mathrm{Ab}$ & $6.55( \pm 0.10) \mathrm{Aa}$ & $0.05( \pm 0.01) \mathrm{Ba}$ & $0.03( \pm 0.01) \mathrm{Bb}$ \\
\hline \multirow{2}{*}{ NT } & sunn hemp & $1.63( \pm 0.07) \mathrm{Aa}$ & $1.67( \pm 0.05) \mathrm{Aa}$ & $2.31( \pm 0.13) \mathrm{Ab}$ & $6.27( \pm 0.48) \mathrm{Aa}$ & $0.05( \pm 0.01) \mathrm{Ba}$ & $0.04( \pm 0.01) \mathrm{Aa}$ \\
\hline & bean/millet & $1.58( \pm 0.03) \mathrm{ABb}$ & $1.71( \pm 0.05) \mathrm{Aa}$ & $1.94( \pm 0.04) \mathrm{Bb}$ & $4.07( \pm 0.01) \mathrm{Ca}$ & $0.06( \pm 0.02) \mathrm{Ba}$ & $0.03( \pm 0.01) \mathrm{Bb}$ \\
\hline
\end{tabular}

Means ( \pm standard error) followed by different uppercase letter within the same cover crop and soil layer indicate differences between tillage practices; Different lowercase letters indicate difference between soil layers within the same tillage and cover crop, and bold number indicates difference between cover crops within the same tillage and soil layer. Differences were analyzed using Tukey's post-hoc test at $p<0.05$.
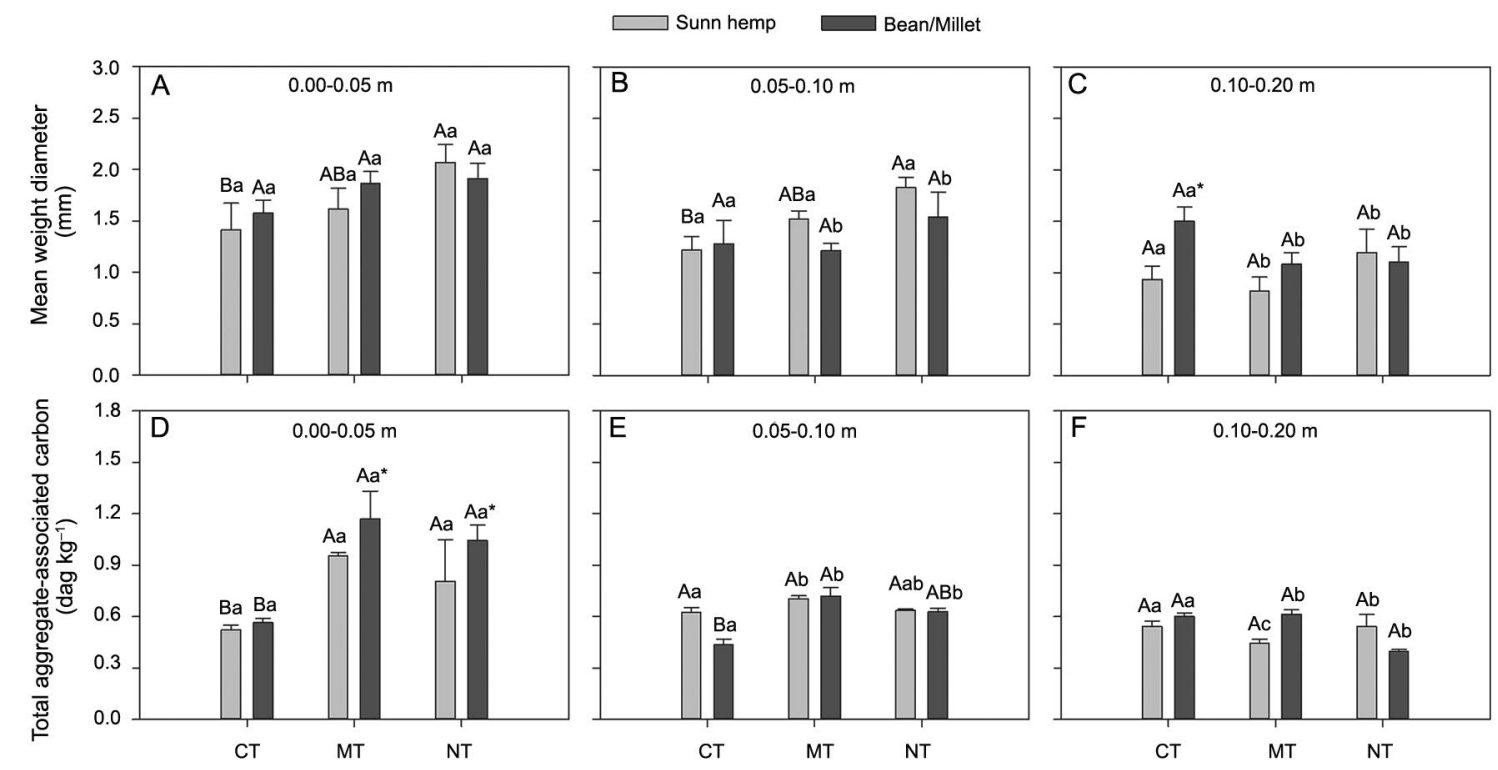

Figure 1 - Mean weight diameter of water-stable aggregates and total aggregate-associated carbon content in different soil layers [0.00-0.05 ( $A$ and $D), 0.05-0.10$ ( $B$ and $E$ ) and $0.10-0.20 \mathrm{~m}$ (C and F)] in the $16^{\text {th }}$ year of conventional (CT), minimum (MT) and no-tillage (NT) practices adoption. Bars represent mean values and error bars one standard error. Bars with same uppercase letter within each soil layer and cover crop denote that tillage practices are not significantly different; same lowercase letter within a tillage practice and cover crop denotes that soil layers are not significantly different; asterisks indicate significant difference between cover crops within same tillage practice and soil layer. Differences were analyzed using Tukey's post-hoc test at $p<0.05$. 
treatments, while it was lower in CT $\left(0.44 \mathrm{dag} \mathrm{kg}^{-1}\right)$ than in MT (0.72 dag $\left.\mathrm{kg}^{-1}\right)$ when bean/millet was cropped (Figure 1E). The bean/millet sequence enhanced total aggregate-C content in the 0.00-0.05 $\mathrm{m}$ soil layer in MT and NT (Figure 1D). Similar to MWD, total aggregate-C content in conservation tillage (MT and NT) decreased with the soil depth (Figure 1D, E and F). Neither tillage practices nor cover crops induced changes in total aggregate-C content in the $0.10-0.20 \mathrm{~m}$ soil layer (Figure $1 \mathrm{~F}$ ).

\section{Discussion}

Long-term experiments may provide more reliable assessments and minimize the varied $\mathrm{Bd}$ response (increase, decrease or null effects) to tillage practices observed across a wide range of soil types (Lozano et al., 2016; Obalum and Obi, 2010). Changes in Bd caused by tillage are frequently overshadowed by short-term alterations in SOM content (Heuscher et al., 2005 ), soil water regime and crop rooting (Strudley et al., 2008).

Annual plowing was expected to reduce soil compaction by the maintaining of a fairly loose structure or increasing soil porosity (Dam et al., 2005). However, CT adoption resulted in higher Bd compared with MT (Table 1). Probably, the enhancement of $\mathrm{C}$ oxidation stimulated by intensive soil disturbance during CT practices (Figure 1D and E) led to increased Bd values, as previously reported for low-C soils (Keller and Håkansson, 2010). However, our findings did not entirely align with the opposite assumption, i.e., a reduced intensity in soil manipulation that leads to higher SOC content could also promote Bd reduction (Parihar et al., 2016). Herein, no differences in total aggregate-C content between NT and MT were observed, but NT presented increased Bd (Figure 1D, E and F; Table 1). Cumulative pressure from machinery traffic, particle resettlement and macroporosity reduction are frequently related to soil compaction in NT systems (Silva et al., 2012; Strudley et al., 2008). Thus, our findings indicated that SOC alone cannot alleviate soil compaction to a critical level, but low-intensity tillage practices may soften compaction while not reducing the accrual of SOC.

It is important to highlight that our experiment simulated one single corn cultivation per year. Increases in $\mathrm{Bd}$ may be intensified at sites where irrigation allows for more than one cultivation per year, which is a common practice in the region. Concerns about $\mathrm{Bd}$ increase are relevant because soil compaction has demonstrated negative impacts on corn nutrient uptake (Miransari et al., 2009), growth (Abu-Hamdeh, 2003) and yields (Gregorich et al., 2011). In particular, the soil studied here had already presented a natural hardsetting behavior which imposes physical restriction on plant roots exploring deeper horizons, and consequently, a greater $\mathrm{Bd}$ in the upper soil layer $(0.20 \mathrm{~m}$ depth) could exacerbate such restriction. For instance, in the year studied, the corn ear index (total ear number/total plant number) in NT was $~ 30 \%$ lower than in MT (data not shown).

A distinct degree of water saturation can lead to differences in SPR values, whereby drier conditions would enhance soil strength, such as SPR (Busscher et al., 1997; Gao et al., 2012). In the present study, where tillage and cover crops were also influencing soil moisture and SPR (Table 1), this relationship, however, was not straightforward. No-tillage in combination with bean/millet sequence showed the lowest SPR in the 0.20 $\mathrm{m}$ depth even under the driest soil moisture condition compared to CT or NT/sunn hemp treatments (Table 1). Biopores produced by plant roots and soil fauna are particularly important in undisturbed soils (Angers and Caron, 1998) where their preservation creates a network of channels whereby subsequent crop roots easily propagate (Suzuki et al., 2013), hindering possible negative alterations in $\mathrm{Bd}$. Thus, the deeper and dense root system of millet combined with the probable preserved biopores from beans compared with fewer roots of sunn hemp taproot system (Calonego et al., 2017) seem to offer an effective solution to reducing the soil physical constraints to plant growth in Ultisols under the NT system.

The lack of soil disturbance and cover cropping have been related to mechanisms of water-stable aggregates formation, and assume greater importance in soils with low clay content and kaolinite predominance (Six et al., 2002b). Moreover, the slow macroaggregate turnover and its preservation in NT systems foster microaggregate formation within macroaggregates which is, in turn, effective for avoiding SOC oxidation (Dungait et al., 2012; Six et al., 2000a). In fact, in the present study, increased MWD at the $0.10 \mathrm{~m}$ depth was observed in NT systems compared with CT, but MWD did not differ between NT and MT (Figure 1A and B). Meanwhile, the total aggregate- $C$ content in the 0.10 $\mathrm{m}$ depth found in NT and MT was higher than in CT, with a greater difference between tillage practices attributable to the adoption of the bean/millet sequence (Figure 1D and E).

It is intriguing that the adoption of harrowing in the $0.20 \mathrm{~m}$ depth in MT operations did not reduce aggregate stability compared with NT. The closer contact between cover crop residues and the soil microbial population in MT probably enhanced plant biomass decomposition and increased the particulate organic matter content (Dungait et al., 2012). Particulate organic matter plays a key role in aggregate formation, providing a binding agent for the formation of microaggregates (Beare et al., 1994). Furthermore, the low intensity of soil disturbance, i.e. only harrowing, might have promoted a stabilizing effect of clay particles on SOC (Six et al., 2002b). Thus, the feedback mechanism between mineral-andorganic particle contact, the accrual of SOC and soil aggregation (Beare et al., 1994; Six et al., 2000b) ensured the findings in the MT system. Conversely, a more thorough soil disturbance and incorporation of cover crop 
residues due to $\mathrm{CT}$ operations led to a decrease in total aggregate-C content in the uppermost soil layer (Figure 1D and E) but did not affect it nor the MWD in deeper soil layers (Figures $1 \mathrm{C}$ and F). Therefore, the intensity of soil disturbance exerts a strong effect on soil aggregation and the accrual of SOC of weakly structured soils, but its influence is greater on surface layers.

Combining bean with millet as cover crops showed remarkable potential for increasing total aggregate- $\mathrm{C}$ in the $0.00-0.05 \mathrm{~m}$ soil layer, when associated with conservation tillage practices (Figure 1D), and for increasing MWD in deeper soil layers under CT (Figure $1 \mathrm{C})$. The sunn hemp crop-based rotation has the disadvantage of a lower number of species which could have led to lower soil microbial diversity and thus reduced SOC (McDaniel et al., 2014). Furthermore, a faster decomposability of their residues due to its lower $\mathrm{C} / \mathrm{N}$ ratio (Berg, 2014) might also be a disadvantage in a sandy, warm, and irrigated environment which probably resulted in lower aggregate stability and total aggregate-C content (Chivenge et al., 2011). Within the framework of agricultural production and the modest capacity for long-term SOC storage of sandy soils (Chivenge et al., 2007), even a slight SOC increment may positively influence sweet corn productivity (Oliveira et al., 2017) and maintain soil quality under the climate and soil conditions studied.

\section{Conclusions}

The results provided here support the ideas behind conservation tillage systems, i.e. their benefits for soil quality. Compared with $\mathrm{CT}$, the positive effects of conservation tillage systems on the accrual of SOC and soil aggregation are concentrated in the upper 0.00 $0.10 \mathrm{~m}$ soil layer, while on soil $\mathrm{Bd}$ and SPR they extend to deeper layers $(0.10-0.20 \mathrm{~m})$. The bean/millet sequence performed better in terms of improving soil quality than sunn hemp. These results suggest that the beneficial effects of conservation tillage on soil physical properties and the accrual of SOC are reliant on the proper choice of cover crop species. The low intensity of soil disturbance caused by the adoption of MT may not be harmful to soil aggregation and SOC, while avoiding Bd increase. Thereby, MT assumes greater importance in long-term improvement of soil functioning and prevention of soil degradation of weakly structured Ultisols on the coastal tableland in northeastern Brazil.

\section{Acknowledgments}

We thank the CAPES Foundation (Coordenação de Aperfeiçoamento de Pessoal de Nível Superior) and the FAPITEC/SE (Fundação de Apoio à Pesquisa e à Inovação Tecnológica do Estado de Sergipe - grant $\mathrm{n}^{\circ}$ 019.203.00464/2016-6) for providing funds for this research and a scholarship to the first author.

\section{Authors' Contributions}

Conceptualization: Pedrotti, A. Data acquisition: Oliveira, F.C.C.; Souza, J.L.S.; Vieira, M.E.O. Data analysis: Oliveira, F.C.C.; Ferreira, G.W.D. Design of methodology: Oliveira, F.C.C.; Ferreira, G.W.D. Writing and editing: Oliveira, F.C.C.; Ferreira, G.W.D.; Souza, J.L.S.; Vieira, M.E.O.; Pedrotti, A.

\section{References}

Abu-Hamdeh, N.H. 2003. Compaction and subsoiling effects on corn growth and soil bulk density. Soil Science Society of America Journal 67: 1213-1219.

Alvares, C.A.; Stape, J.L.; Sentelhas, P.C.; Gonçalves, J.L.M.; Spavorek, G. 2013. Köppen's climate classification map for Brazil. Meteorologische Zeitschrift 22: 711-728.

Angers, D.; Caron, J. 1998. Plant-induced changes in soil structure: processes and feedbacks. Biogeochemistry 42: 55-72.

Beare, M.H.; Hendrix, P.F.; Coleman, D.C. 1994. Water-stable aggregates and organic matter fractions in conventional- and no-tillage soils. Soil Science Society of America Journal 58: 777795.

Berg, B. 2014. Decomposition patterns for foliar litter: a theory for influencing factors. Soil Biology and Biochemistry 78: 222232.

Busscher, W.J.; Bauer, P.J.; Camp, C.R.; Sojka, R.E. 1997. Correction of cone index for soil water content differences in a coastal plain soil. Soil and Tillage Research 43: 205-217.

Calonego, J.C.; Raphael, J.P.A.; Rigon, J.P.G.; Oliveira Neto, L.; Rosolem, C.A. 2017. Soil compaction management and soybean yields with cover crops under no-till and occasional chiseling. European Journal of Agronomy 85: 31-37.

Carvalho, D.F.; Durigon, V.L.; Antunes, M.A.H.; Almeida, W.S.; Oliveira, P.T.S. 2014. Predicting soil erosion using Rusle and NDVI time series from TM Landsat 5. Pesquisa Agropecuária Brasileira 49: 215-224.

Chivenge, P.P.; Murwira, H.K.; Giller, K.E.; Mapfumo, P.; Six, J. 2007. Long-term impact of reduced tillage and residue management on soil carbon stabilization: implications for conservation agriculture on contrasting soils. Soil and Tillage Research 94: 328-337.

Chivenge, P.P.; Vanlauwe, B.; Gentile, R.; Six, J. 2011. Organic resource quality influences short-term aggregate dynamics and soil organic carbon and nitrogen accumulation. Soil Biology and Biochemistry 43: 657-666.

Dam, R.F.; Mehdi, B.B.; Burgess, M.S.E.; Madramootoo, C.A.; Mehuys, G.R.; Callum, I.R. 2005. Soil bulk density and crop yield under eleven consecutive years of corn with different tillage and residue practices in a sandy loam soil in central Canada. Soil and Tillage Research 84: 41-53.

Derpsch, R.; Franzluebbers, A.J.; Duiker, S.W.; Reicosky, D.C.; Koeller, K.; Friedrich, T.; Sturny, W.G.; Sá, J.C.M.; Weiss, K. 2014. Why do we need to standardize no-tillage research? Soil and Tillage Research 137: 16-22.

Dungait, J.A.J.; Hopkins, D.W.; Gregory, A.S.; Whitmore, A.P. 2012. Soil organic matter turnover is governed by accessibility not recalcitrance. Global Change Biology 18: 1781-1796. 
Elliott, E.T. 1986. Aggregate structure and carbon, nitrogen, and phosphorus in native and cultivated soils. Soil Science Society of America Journal 50: 627-633.

Gao, L.; Becker, E.; Liang, G.; Houssou, A.A.; Wu, H.; Wu, X.; Cai, D.; Degré, A. 2017. Effect of different tillage systems on aggregate structure and inner distribution of organic carbon. Geoderma 288: 97-104.

Gao, W.; Watts, C.W.; Ren, T.; Whalley, W.R. 2012. The effects of compaction and soil drying on penetrometer resistance. Soil and Tillage Research 125: 14-22.

Gregorich, E.G.; Lapen, D.R.; Ma, B.L.; McLaughlin, N.B.; VandenBygaart, A.J. 2011. Soil and crop response to varying levels of compaction, nitrogen fertilization, and clay content. Soil Science Society of America Journal 75: 1483-1492.

Heuscher, S.A.; Brandt, C.C.; Jardine, P.M. 2005. Using soil physical and chemical properties to estimate bulk density. Soil Society of America Journal 69: 1-7.

Hubbard, R.K.; Strickland, T.C.; Phatak, S. 2013. Effects of cover crop systems on soil physical properties and carbon/nitrogen relationships in the coastal plain of southeastern USA. Soil and Tillage Research 126: 276-283.

Keller, T.; Håkansson, I. 2010. Estimation of reference bulk density from soil particle size distribution and soil organic matter content. Geoderma 154: 398-406.

Lal, R. 2015. Restoring soil quality to mitigate soil degradation. Sustainability 7 : 5875-5895.

Lozano, L.A.; Soracco, C.G.; Villarreal, R.; Ressia, J.M.; Sarli, G.O.; Filgueira, R.R. 2016. Soil physical quality and soybean yield as affected by chiseling and subsoiling of a no-till soil. Revista Brasileira de Ciência do Solo 40: 1-12.

McDaniel, M.D.; Tiemann, L.K.; Grandy, A.S. 2014. Does agricultural crop diversity enhance soil microbial biomass and organic matter dynamics? A meta-analysis. Ecological Applications 24: 560-570.

Miransari, M.; Bahrami, H.A.; Rejali, F.; Malakouti, M.J. 2009. Effects of soil compaction and arbuscular mycorrhiza on corn (Zea mays L.) nutrient uptake. Soil and Tillage Research 103: 282-290.

Moraes, M.T.; Debiasi, H.; Carlesso, R.; Franchini, J.C.; Silva, V.R.; Luz, F.B. 2016. Soil physical quality on tillage and cropping systems after two decades in the subtropical region of Brazil. Soil and Tillage Research 155: 351-362.

Obalum, S.E.; Obi, M.E. 2010. Physical properties of a sandy loam Ultisol as affected by tillage-mulch management practices and cropping systems. Soil and Tillage Research 108: 30-36.

Oliveira, F.C.C.; Pedrotti, A.; Felix, A.G.S.; Souza, J.L.S.; Holanda, F.S.R.; Mello Junior, A.V. 2017. Chemical characteristics of Ultisols and the corn yield at Coastal Tableland of Sergipe, Brazil. Revista Brasileira de Ciências Agrárias 12: 354-360 (in Portuguese, with abstract in English).

Parihar, C.M.; Yadav, M.R.; Jat, S.L.; Singh, A.K.; Kumar, B.; Pradhan, S.; Chakraborty, D.; Jat, M.L.; Jat, R.K.; Saharawat, Y.S.; Yadav, O.P. 2016. Long term effect of conservation agriculture in maize rotations on total organic carbon, physical and biological properties of a sandy loam soil in north-western Indo-Gangetic Plains. Soil and Tillage Research 161: 116-128.
Sá, J.C.M.; Cerri, C.C.; Lal, R.; Dick, W.A.; Piccolo, M.C.; Feigl, B.E. 2009. Soil organic carbon and fertility interactions affected by a tillage chronosequence in a Brazilian Oxisol. Soil and Tillage Research 104: 56-64.

Silva, S.G.C.; Silva, Á.P.; Giarola, N.F.B.; Tormena, C.A.; Sá, J.C.M. 2012. Temporary effect of chiseling on the compaction of a Rhodic Hapludox under no-tillage. Revista Brasileira de Ciência do Solo 36: 547-555.

Six, J.; Bossuyt, H.; Degryze, S.; Denef, K. 2004. A history of research on the link between (micro)aggregates, soil biota, and soil organic matter dynamics. Soil and Tillage Research 79: 7-31.

Six, J.; Conant, R.T.; Paul, E.A.; Paustian, K. 2002a. Stabilization mechanisms of soil organic matter: implications for C-saturation of soils. Plant and Soil 241: 155-176.

Six, J.; Elliott, E.T.; Paustian, K. 2000a. Soil structure and soil organic matter. II. A normalized stability index and the effect of mineralogy. Soil Science Society of America Journal 64: 1042-1049.

Six, J.; Elliott, E.T.; Paustian, K. 2000b. Soil macroaggregate turnover and microaggregate formation: a mechanism for $\mathrm{C}$ sequestration under no-tillage agriculture. Soil Biology and Biochemistry 32: 2099-2103.

Six, J.; Feller, C.; Denef, K.; Ogle, S.; Sá, J.C.M.; Albrecht, A. 2002b. Soil organic matter, biota and aggregation in temperate and tropical soils: effects of no-tillage. Agronomie 22: 755-775.

Six, J.; Paustian, K. 2014. Aggregate-associated soil organic matter as an ecosystem property and a measurement tool. Soil Biology and Biochemistry 68: A4-A9.

Sobral, L.F.; Viegas, P.R.A.; Siqueira, O.J.W.; Anjos, J.L.; Barreto, M.C.V.; Gomes, J.B.V. 2007. Recommendations for Liming and Fertilizer Uses in Sergipe State. = Recomendações para o uso de corretivos e fertilizantes no estado de Sergipe. Embrapa Tabuleiros Costeiros, Aracaju, SE, Brazil (in Portuguese).

Soil Survey Staff. 2014. Keys to Soil Taxonomy. 12ed. USDANatural Resources Conservation Service, Washington, DC, USA.

Strudley, M.W.; Green, T.R.; Ascough, J.C. 2008. Tillage effects on soil hydraulic properties in space and time: state of the science. Soil and Tillage Research 99: 4-48.

Suzuki, L.E.A.S.; Reichert, J.M.; Reinert, D.J. 2013. Degree of compactness, soil physical properties and yield of soybean in six soils under no-tillage. Soil Research 51: 311-321.

Yeomans, J.C.; Bremner, J.M. 1988. A rapid and precise method for routine determination of organic carbon in soil. Communications in Soil Science and Plant Analysis 13: 14671476. 